Arch. Environ. Contam. Toxicol. 18, 656-668 (1989)

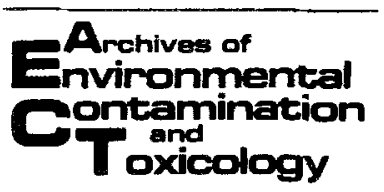

(C) 1989 Springer-Verlag New York Inc.

\title{
Effects of Chlorinated Benzenes on Diatom Fatty Acid Composition and Quantitative Morphology. IV. Pentachlorobenzene and Comparison with Trichlorobenzene Isomers
}

\author{
L. Sicko-Goad, M. S. Evans, D. Lazinsky, J. Hall, and M. S. Simmons \\ Great Lakes Research Division, The Institute of Science and Technology, The University of Michigan, \\ Ann Arbor, Michigan 48109, USA
}

\begin{abstract}
Cells of the diatom Cyclotella meneghiniana were exposed in a closed system to 0.095 ppm pentachlorobenzene over a period of 5 days. Changes in fatty acid and morphological percent composition were monitored to determine the effect of the toxicant. The greatest morphological change observed was an increase in lipid volume. Most morphological changes occurred in the 1 hour and 5 day sampling periods. Few changes in morphological characteristics or fatty acid percent composition were observed at eight hours, when the cells were in the dark. The C18:1 and C20:5 fatty acids were most variable with exposure to pentachlorobenzene. Results suggest that at sublethal doses, lipophilic toxicants exert effects that are biphasic. That is, immediately measurable effects are observed in the cells that include increases in storage products and changes in membranous organelles. Long-term effects are postulated to be the result of mobilization of lipophilic toxicants that have partitioned into lipid stores and are more available when lipids are metabolized. Although pentachlorobenzene has a higher octanol/water partition coefficient, it appears to exert fewer cellular changes than any trichlorobenzene isomer.
\end{abstract}

Previous work in our laboratory (Sicko-Goad et al. 1989a, 1989b, 1989c, 1988) has suggested that toxicity of chlorinated benzenes to diatoms is dependent on a variety of parameters including the physiological state of the cell, environmental parameters, and structure-activity relationships of the toxicant. In addition, we have shown that exposure to sub-lethal doses of trichlorinated benzenes having similar octanol-water partition coefficients produces changes in fatty acid composition and quantitative morphology that vary in number, timing, and magnitude. Although the number of detrimental effects relates to relative reactivity, it is apparent that the physiological state of the cell, particularly lipid content, plays an important role in determining response to lipophilic toxicants.

Pentachlorobenzene has been reported to be more toxic to and have a greater bioaccumulation factor in freshwater algae and a variety of other organisms than the trichlorobenzene isomers (Wong et al. 1984; Geyer et al. 1984; Halfon and Reggiani 1986). Toxicity and lipophilicity of chlorinated benzenes are believed to increase with increasing chlorination. The following report is the fourth paper in a series reporting changes in fatty acid composition and quantitative morphology in the diatom, Cyclotella meneghiniana, on exposure to chlorinated benzenes and reports the results of exposure to pentachlorobenzene.

\section{Materials and Methods}

For the pentachlorobenzene exposure experiment, $3 \mathrm{~L}$ of 7-dayold exponential phase cells of the diatom Cyclotella meneghiniana at a density of $102,000 \mathrm{cells} / \mathrm{ml}$ were exposed to the chemical at a concentration of $0.095 \mathrm{ppm}$, since the solubility of pentachlorobenzene in water is considerably less than trichlorobenzene. However, in this experiment, as with the trichlorobenzene isomers, concentration was well below maximum water solubility and no carrier such as acetone was used to facilitate dissolution. Cells were withdrawn by aspiration at $10 \mathrm{~min}, 1 \mathrm{hr}, 2 \mathrm{hr}, 8$ $\mathrm{hr}, 24 \mathrm{hr}$, and 5 days for fatty acid analysis. For electron microscopy, only 3 time samples were analyzed: $1 \mathrm{hr}, 8 \mathrm{hr}$, and 5 days. In terms of chronological sequence, this was the first of the four experiments run, and in subsequent experiments with exposure to the trichlorobenzene isomers, more detailed time analyses of morphological components were carried out. 

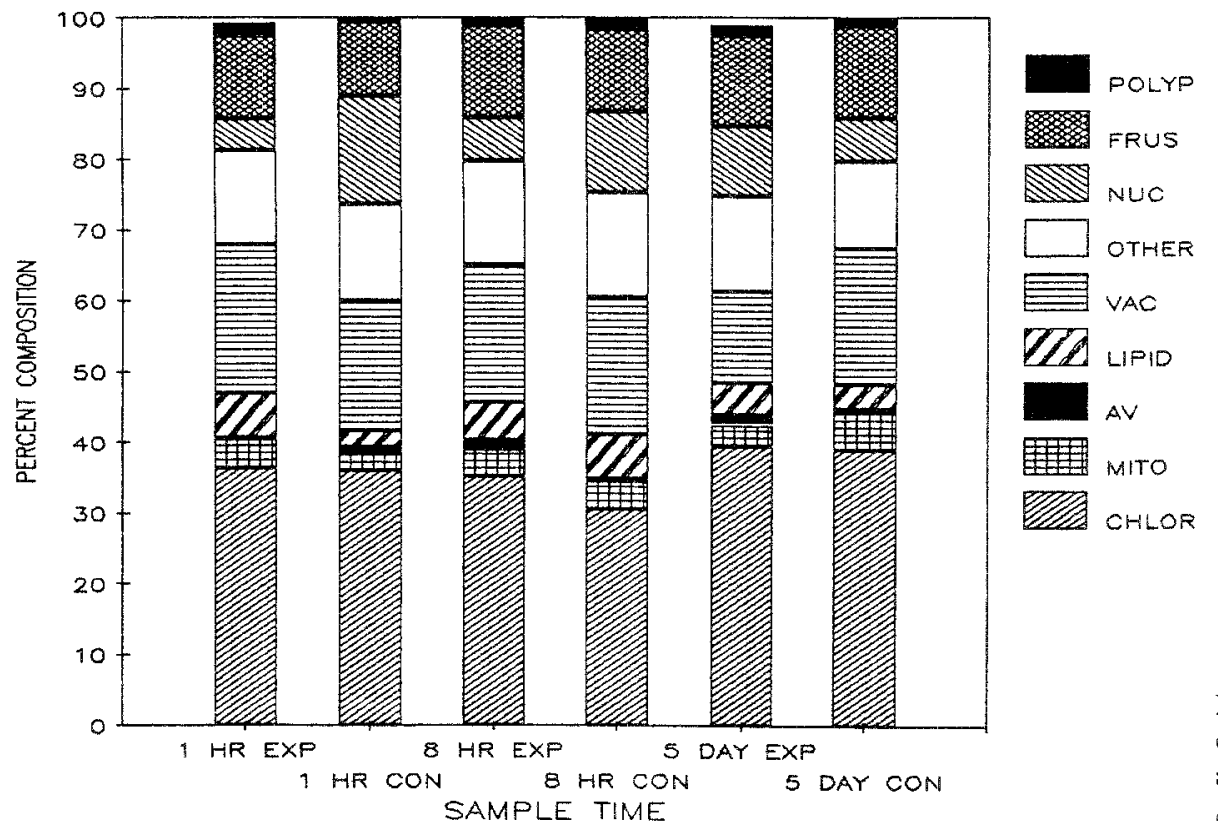

Fig. 1. Morphological percent composition of experimental (EXP) and control (CON) cells of Cyclotella meneghiniana.

Table 1. Relative volumes (\% composition) and numbers per volume of cellular components of Cyclotella meneghiniana control cells and cells exposed to $0.245 \mathrm{ppm}$ pentachlorobenzene (with standard errors). Values reported are the mean ( \pm 1 S.E.) of a sample size of 25

\begin{tabular}{|c|c|c|c|c|c|c|}
\hline \multirow[b]{2}{*}{ Cell component } & \multicolumn{6}{|c|}{ Experimental treatment } \\
\hline & $\begin{array}{l}1 \mathrm{hr} \\
\text { Control }\end{array}$ & $\begin{array}{l}1 \mathrm{hr} \\
\text { Exposed }\end{array}$ & $\begin{array}{l}8 \mathrm{hr} \\
\text { Control }\end{array}$ & $\begin{array}{l}8 \mathrm{hr} \\
\text { Exposed }\end{array}$ & $\begin{array}{l}5 \text { day } \\
\text { Control }\end{array}$ & $\begin{array}{l}5 \text { day } \\
\text { Exposed }\end{array}$ \\
\hline Chloroplast $V_{v}$ & $\begin{array}{l}34.1 \\
(1.9)\end{array}$ & $\begin{array}{l}35.5 \\
(1.7)\end{array}$ & $\begin{array}{l}30.0 \\
(2.4)\end{array}$ & $\begin{array}{l}34.3 \\
(1.9)\end{array}$ & $\begin{array}{l}37.8 \\
(2.0)\end{array}$ & $\begin{array}{l}37.4 \\
(2.1)\end{array}$ \\
\hline Chloroplast lipid $\mathrm{V}_{\mathrm{v}}$ & $\begin{array}{l}0.9 \\
(0.2)\end{array}$ & $\begin{array}{c}0.9 \\
(0.2)\end{array}$ & $\begin{array}{c}0.7 \\
(0.1)\end{array}$ & $\begin{array}{c}0.8 \\
(0.1)\end{array}$ & $\begin{array}{c}1.3 \\
(0.2)\end{array}$ & $\begin{array}{c}2.1 \\
(0.3)\end{array}$ \\
\hline Mitochondria $\mathrm{V}_{\mathrm{v}}$ & $\begin{array}{c}2.7 \\
(0.5)\end{array}$ & $\begin{array}{c}4.1 \\
(0.6)\end{array}$ & $\begin{array}{c}3.9 \\
(0.4)\end{array}$ & $\begin{array}{c}3.8 \\
(0.5)\end{array}$ & $\begin{array}{l}5.5 \\
(1.0)\end{array}$ & $\begin{array}{c}3.1 \\
(0.6)\end{array}$ \\
\hline $\begin{array}{l}\text { Autophagic-like } \\
\text { vacuole } V_{v}\end{array}$ & $\begin{array}{c}0.6 \\
(0.2)\end{array}$ & $\begin{array}{c}0.2 \\
(0.1)\end{array}$ & $\begin{array}{c}0.3 \\
(0.1)\end{array}$ & $\begin{array}{c}1.2 \\
(0.3)\end{array}$ & $\begin{array}{c}0.2 \\
(0.2)\end{array}$ & $\begin{array}{c}1.4 \\
(0.3)\end{array}$ \\
\hline Lipid $V_{v}$ & $\begin{array}{c}2.4 \\
(0.7)\end{array}$ & $\begin{array}{c}6.3 \\
(1.7)\end{array}$ & $\begin{array}{c}6.3 \\
(2.1)\end{array}$ & $\begin{array}{c}5.2 \\
(1.1)\end{array}$ & $\begin{array}{c}3.5 \\
(1.5)\end{array}$ & $\begin{array}{l}4.5 \\
(1.3)\end{array}$ \\
\hline Vacuole $V_{v}$ & $\begin{array}{l}18.3 \\
(2.0)\end{array}$ & $\begin{array}{l}21.0 \\
(1.9)\end{array}$ & $\begin{array}{l}19.4 \\
(2.3)\end{array}$ & $\begin{array}{l}19.6 \\
(1.9)\end{array}$ & $\begin{array}{l}19.2 \\
(2.5)\end{array}$ & $\begin{array}{l}12.9 \\
(1.9)\end{array}$ \\
\hline Other & $\begin{array}{l}13.7 \\
(1.1)\end{array}$ & $\begin{array}{l}13.4 \\
(1.3)\end{array}$ & $\begin{array}{l}14.8 \\
(1.3)\end{array}$ & $\begin{array}{l}14.7 \\
(0.9)\end{array}$ & $\begin{array}{l}12.4 \\
(1.3)\end{array}$ & $\begin{array}{l}13.5 \\
(1.1)\end{array}$ \\
\hline Nucleus $\mathrm{V}_{\mathrm{v}}$ & $\begin{array}{l}15.2 \\
(2.1)\end{array}$ & $\begin{array}{c}4.4 \\
(1.2)\end{array}$ & $\begin{array}{l}11.4 \\
(2.3)\end{array}$ & $\begin{array}{c}6.0 \\
(1.9)\end{array}$ & $\begin{array}{l}6.1 \\
(2.0)\end{array}$ & $\begin{array}{l}10.8 \\
(2.2)\end{array}$ \\
\hline Frustule $\mathrm{V}_{\mathrm{v}}$ & $\begin{array}{l}10.5 \\
(0.5)\end{array}$ & $\begin{array}{l}11.5 \\
(0.6)\end{array}$ & $\begin{array}{l}11.6 \\
(0.6)\end{array}$ & $\begin{array}{l}12.9 \\
(0.9)\end{array}$ & $\begin{array}{l}12.8 \\
(0.9)\end{array}$ & $\begin{array}{l}12.5 \\
(0.8)\end{array}$ \\
\hline Polyphosphate $\mathrm{V}_{\mathrm{v}}$ & $\begin{array}{c}1.6 \\
(0.3)\end{array}$ & $\begin{array}{c}2.0 \\
(0.4)\end{array}$ & $\begin{array}{c}1.6 \\
(0.4)\end{array}$ & $\begin{array}{c}1.4 \\
(0.3)\end{array}$ & $\begin{array}{l}1.2 \\
(0.5)\end{array}$ & $\begin{array}{l}1.7 \\
(0.3)\end{array}$ \\
\hline $\begin{array}{c}\text { Chloroplast } N_{V} \\
\left(/ \mu \mathrm{m}^{3} \text { cell }\right)\end{array}$ & $\begin{array}{c}0.12 \\
(0.02)\end{array}$ & $\begin{array}{c}0.10 \\
(0.02)\end{array}$ & $\begin{array}{c}0.11 \\
(0.01)\end{array}$ & $\begin{array}{c}0.02 \\
(0.02)\end{array}$ & $\begin{array}{c}0.10 \\
(0.01)\end{array}$ & $\begin{array}{c}0.12 \\
(0.01)\end{array}$ \\
\hline $\begin{array}{l}\text { Chloroplast lipid } \mathrm{N}_{\mathrm{V}} \\
\left(/ \mu \mathrm{m}^{3} \text { chloroplast }\right)\end{array}$ & $\begin{array}{c}8.10 \\
(0.22)\end{array}$ & $\begin{array}{c}7.32 \\
(0.26)\end{array}$ & $\begin{array}{l}13.80 \\
(0.39)\end{array}$ & $\begin{array}{l}14.30 \\
(0.44)\end{array}$ & $\begin{array}{c}7.87 \\
(0.29)\end{array}$ & $\begin{array}{l}13.47 \\
(0.44)\end{array}$ \\
\hline $\begin{array}{l}\text { Mitochondria } \mathrm{N}_{\mathrm{v}} \\
\left(/ \mu \mathrm{m}^{3} \text { cell }\right)\end{array}$ & $\begin{array}{c}0.04 \\
(0.01)\end{array}$ & $\begin{array}{c}0.07 \\
(0.01)\end{array}$ & $\begin{array}{c}0.08 \\
(0.01)\end{array}$ & $\begin{array}{c}0.08 \\
(0.01)\end{array}$ & $\begin{array}{c}0.05 \\
(0.01)\end{array}$ & $\begin{array}{c}0.04 \\
(0.01)\end{array}$ \\
\hline $\begin{array}{l}\text { Polyphosphate } \mathrm{N}_{\mathrm{V}} \\
\left(/ \mu \mathrm{m}^{3} \text { cell }\right)\end{array}$ & $\begin{array}{c}0.70 \\
(0.41)\end{array}$ & $\begin{array}{c}0.31 \\
(0.08)\end{array}$ & $\begin{array}{c}0.36 \\
(0.21)\end{array}$ & $\begin{array}{c}0.38 \\
(0.33)\end{array}$ & $\begin{array}{c}0.30 \\
(0.15)\end{array}$ & $\begin{array}{c}0.50 \\
(0.20)\end{array}$ \\
\hline
\end{tabular}



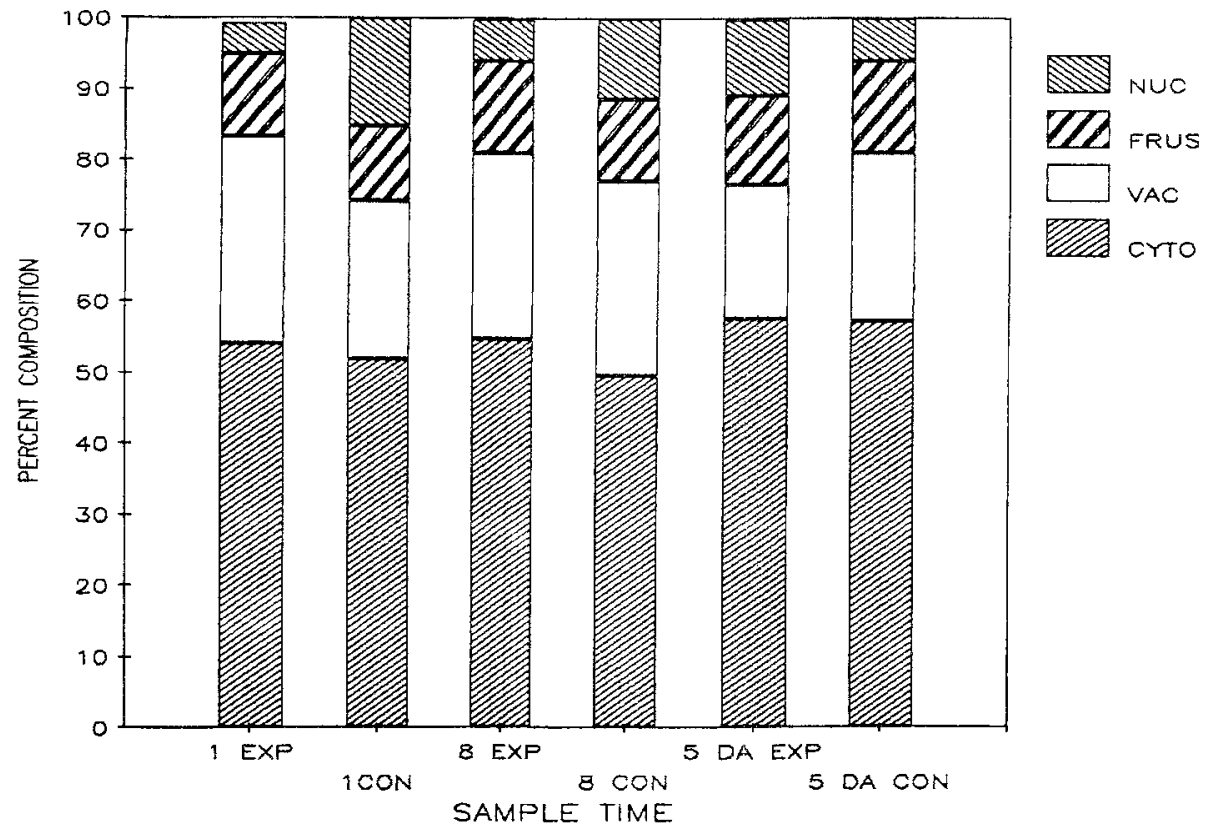

In addition to the changes in chemical concentration and cell densities, this experiment, in terms of sampling in the daily photocycle, was most similar to the 1,2,4-trichlorobenzene experiment. The experiment was initiated at $1230 \mathrm{hr}$, with the $10-\mathrm{min}$, 1-hr, 2-hr, 24-hr, and 5-day samples being withdrawn in the latter part of the light period. The 8 -hr sample was withdrawn 1 and $1 / 2$ hr into the dark period of the photocycle.

\section{Results}

Figure 1 and Table 1 demonstrate that the most pronounced cellular changes that occur on exposure to pentachlorobenzene are the increase in lipid volume for 1-hr and 5-day samples and the large reduction in nuclear volume for the 1 - and 8 -hr exposure samples. This difference in nuclear volume is accentuated when morphological data are regrouped into four major cellular compartments (Figure 2) as previously described (Sicko-Goad et al. $1989 \mathrm{c})$. In addition, Figure 2 also demonstrates that vacuole volume is variable, and the variability cannot be fully explained by the changes in lipid volume, although the lipid is found in the vacuole.

Exposure to pentachlorobenzene results in a short-term increase in mitochondrial volume. However, at 5 days, mitochondrial volume is greater in control cells. Mitochondria are also aberrant in 5day exposed cells (Figure 3). Cristae are less numerous and inclusions are often observed in the mitochondria. Increases in mitochondrial relative volume are accompanied by an increase in numbers per volume. Polyphosphate volume is slightly greater in exposed cells at $1 \mathrm{hr}$ and 5 days. These numbers, however, are not significant. Although fibrous vacuole was not enumerated as a separate category in this experiment, it was observed in the cells adjacent to the chloroplasts (Figure 3 ).

Although there are some significant changes in numbers per volume of chloroplasts, chloroplast lipid droplets, mitochondria, and polyphosphate, there appears to be no consistent pattern of change (Figure 4). However, it should be noted that significant changes that do occur are found in the 1-hr and 5-day sampling periods, with variations of only up to $6 \%$ over controls in the 8 -hr sampling period.

Few significant trends in fatty acid composition are apparent from Figure 5. The most significant fluctuations in percent composition are found in the C18:1 fatty acid, although this fatty acid accounts for only $1-2 \%$ of the total fatty acid percent composition in Cyclotella. It also appears that the levels of the C16 fatty acids are more evenly distributed in percent composition of total fatty acids, although they still comprise approximately $70 \%$ of all fatty acids.

To further discriminate changes occurring as a result of exposure to pentachlorobenzene, increases or decreases for all sampling categories were examined for each time period. Those changes greater than $20 \%$ occurring in morphological components may be summarized as follows:

$1 \mathrm{hr}$-Increases in mitochondria, lipid, and polyphosphate; decreases in autophagic-like vacuole and nucleus.

$8 \mathrm{hr}$-Increase in autophagic-like vacuole; decrease in nucleus. 

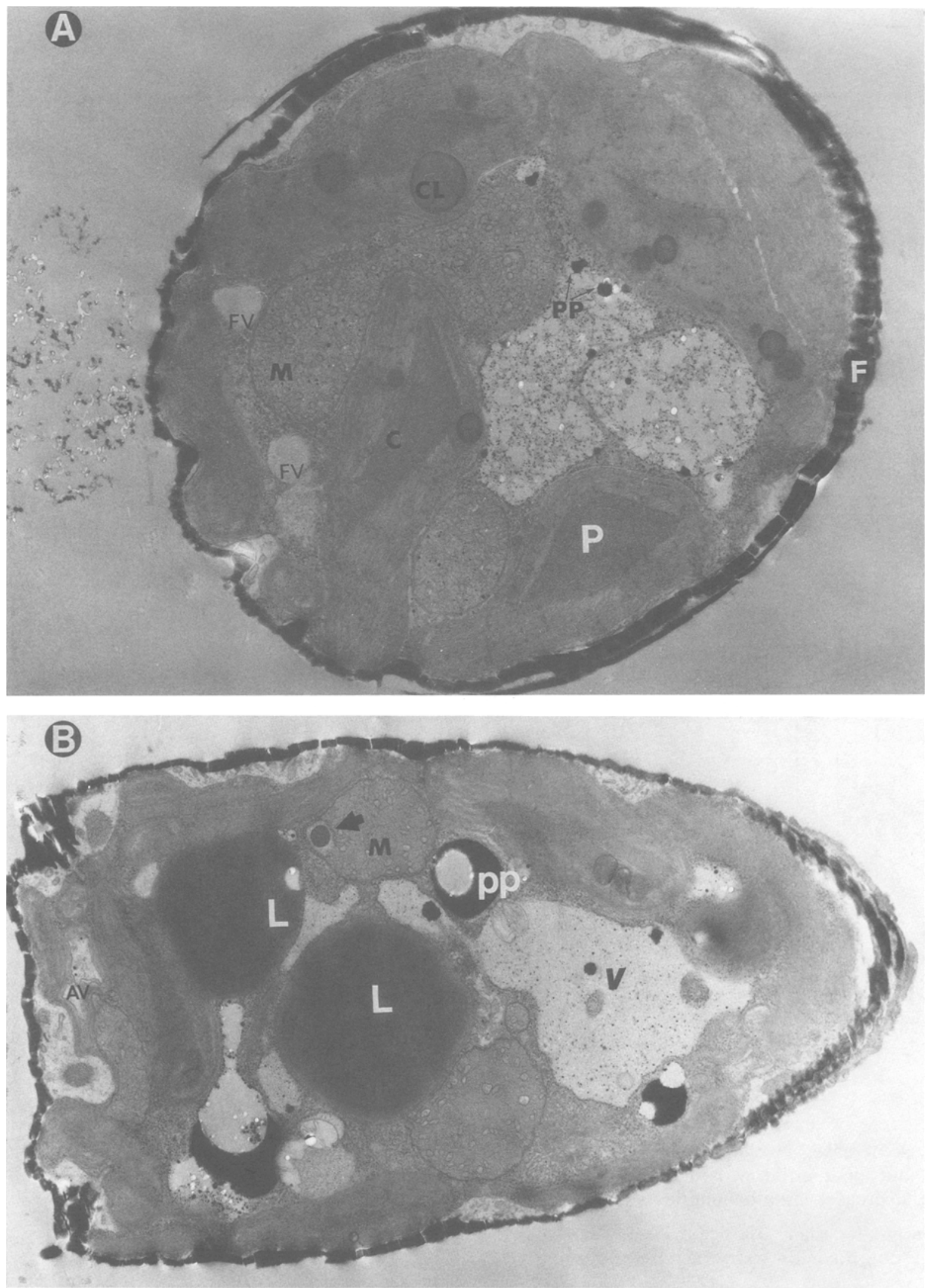

Fig. 3. Electron micrographs of Cyclotella meneghiniana. Key to figure legends: Autophagic-like Vacuole (AV), Chloroplast (C), Chloroplast Lipid (CL), Frustule (F), Fibrous Vacuole (FV), Lipid (L), Mitochondria (M), Pyrenoid (P), Polyphosphate (pp), Vacuole (V). Marker bars $=1 \mu \mathrm{m}$. A Five day control cell. Mitochondria, chloroplast lipid, and pyrenoids are prominent. Small polyphosphate bodies are seen at the periphery of the vacuole. B Five day exposed cell. Lipid and polyphosphate are prominent in the vacuolar region. Mitochondrial cristae appear to be reduced in numbers and mitochondria have inclusions (arrow). Membranous aggregates (AV) are located adjacent to chloroplast and mitochondrion. 


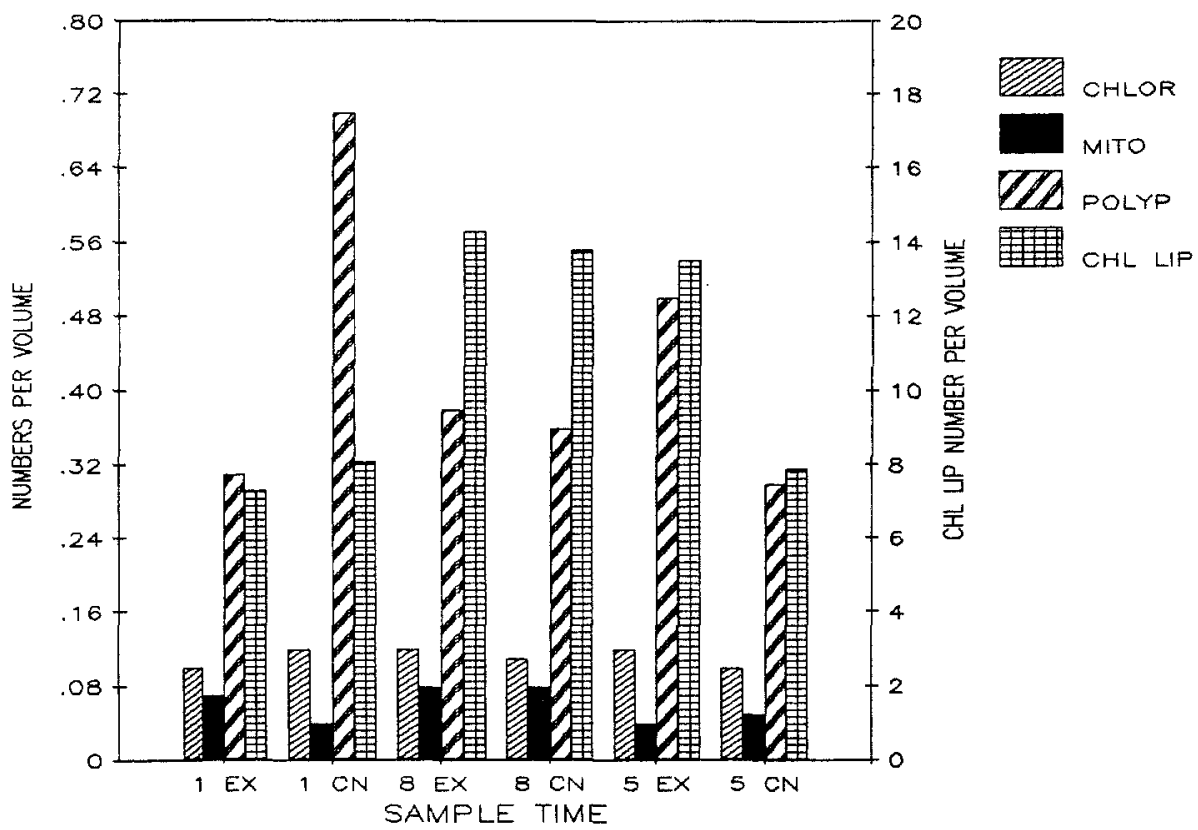

Fig. 4. Numbers per volume of selected organelles. Numbers of chloroplast lipid droplets are reported per $\mu \mathrm{m}^{3}$ chloroplast; all other numbers are reported per $\mu \mathrm{m}^{3}$ cell

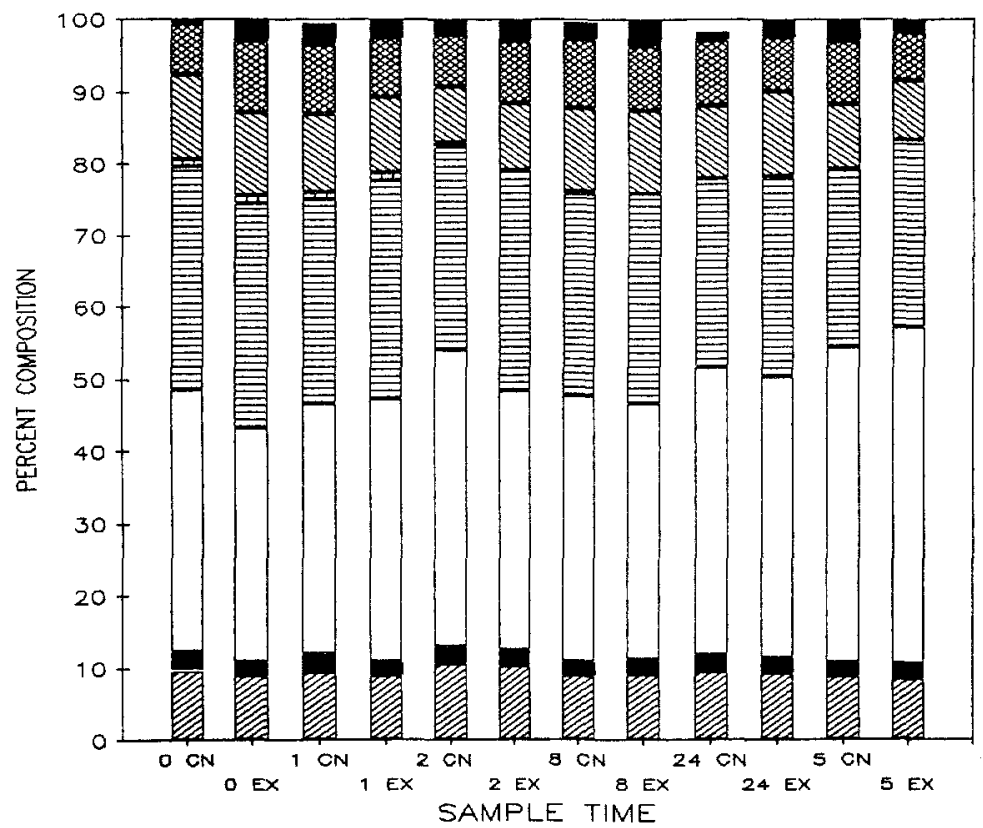

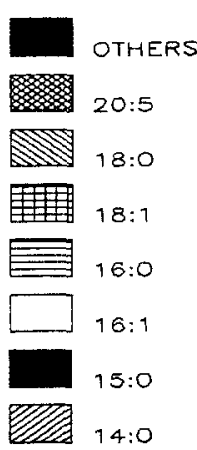

Fig. 5. Change in fatty acid percent composition for all control $(\mathrm{CN})$ and experimental samples. Others represent a composite category of confirmed fatty acids individually present in amounts less than $1 \%$
5 day-Increases in chloroplast lipid, nucleus, lipid, autophagic-like vacuole and polyphosphate; decreases in mitochondria and vacuole.

Changes greater than $20 \%$ occurring in fatty acid percent composition may be summarized as follows:

10 min-Increase in $\mathrm{C} 20: 5$; decrease in C15:0. (Figure 6a)

$1 \mathrm{hr}$-Decrease in C15:0. (Figure 6b)

$2 \mathrm{hr}$-Increase in C18:0; decrease in C18:1. (Figure 7a)
$8 \mathrm{hr}$-Decrease in C18:1. (Figure 7b) $24 \mathrm{hr}$-Increase in C18:1 (Figure 8a) 5 day-Decreases in C18:1 and C20:5 (Figure 8b)

A total number of 19 significant changes occurred in relative volume and numbers per volume categories examined during the three sampling periods. In addition, 9 significant changes occurred in fatty acid percent composition during 6 sampling periods examined. Changes in fatty acid percent composition were evenly distributed with time whereas the morphological changes occurred in the 

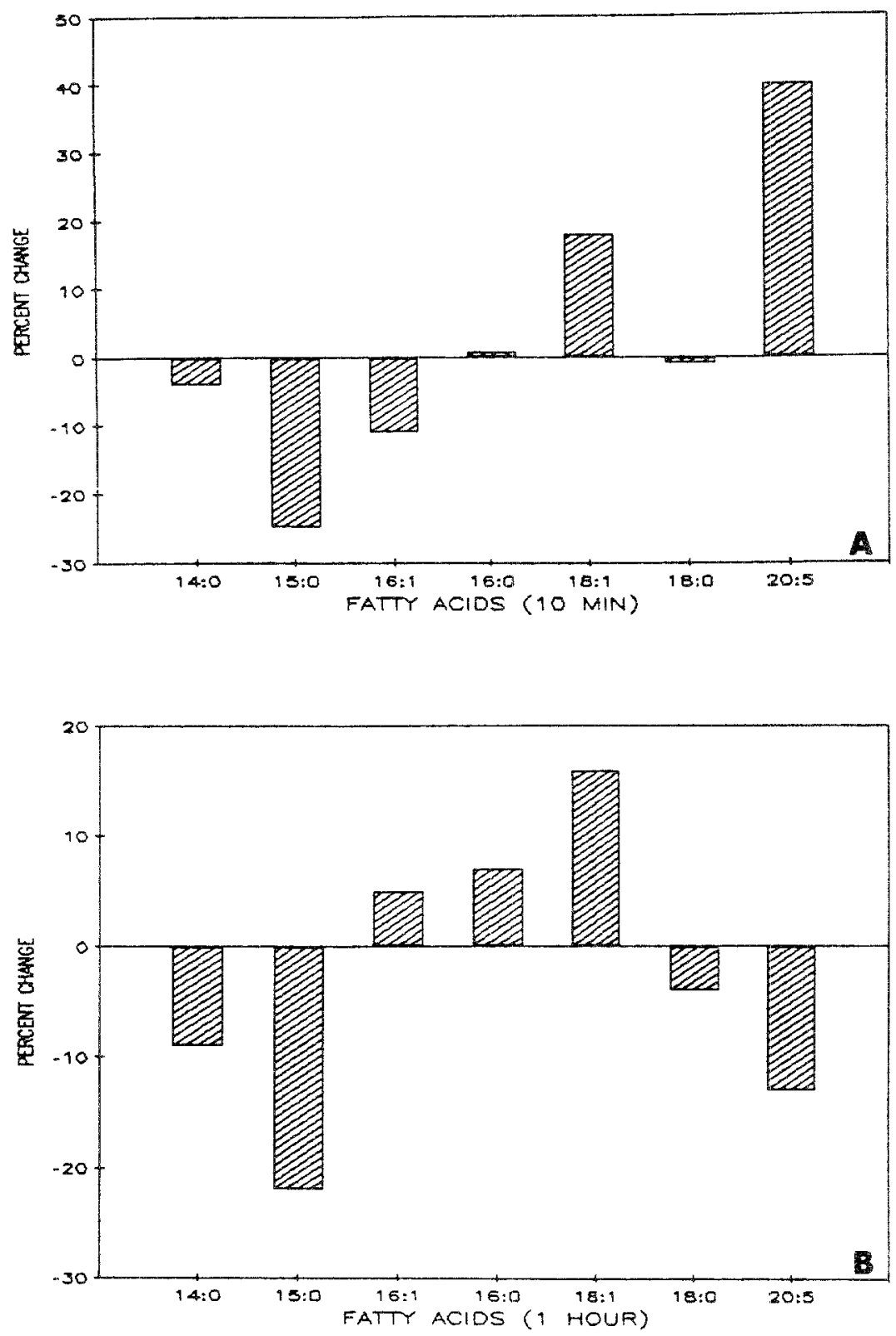

Fig. 6. Changes in fatty acid percent composition with exposure. $10 \mathrm{~min}$ exposure. $1 \mathrm{hr}$ exposure

1-hr and 5-day samples. Autophagic-like vacuole increased by 300 and $600 \%$ in the 8 -hr and 5-day samples, respectively. Overall, lipid and polyphosphate, two storage products, increased with toxicant exposure. The percentage of morphological changes that were significant was similar to the three trichlorobenzene isomers, although there were fewer changes in fatty acids. The C18 fatty acids were most variable with exposure to pentachlorobenzene.

\section{Discussion}

Pentachlorobenzene has an octanol-water partition coefficient $(\log \mathrm{P})$ of 4.88 whereas values for tri- chlorobenzene isomers range from 3.9-4.1 (Wong et al. 1984). Based on this coefficient, one would expect greater partitioning of pentachlorobenzene into lipoprotein membranes (Hutchinson et al. 1980) and greater potential for bioaccumulation. Wong et al. (1984) have demonstrated that, based on the EC50, pentachlorobenzene is much more toxic to Ankistrodesmus falcatus than any of the trichlorinated benzene isomers. Similarly, Geyer et al. (1984) demonstrated that both experimentally determined and calculated bioaccumulation factors for pentachlorobenzene were higher than for trichlorobenzene in Chlorella. These data would suggest that pentachlorobenzene has a greater toxicity potential than any of the less chlorinated benzene derivatives. 

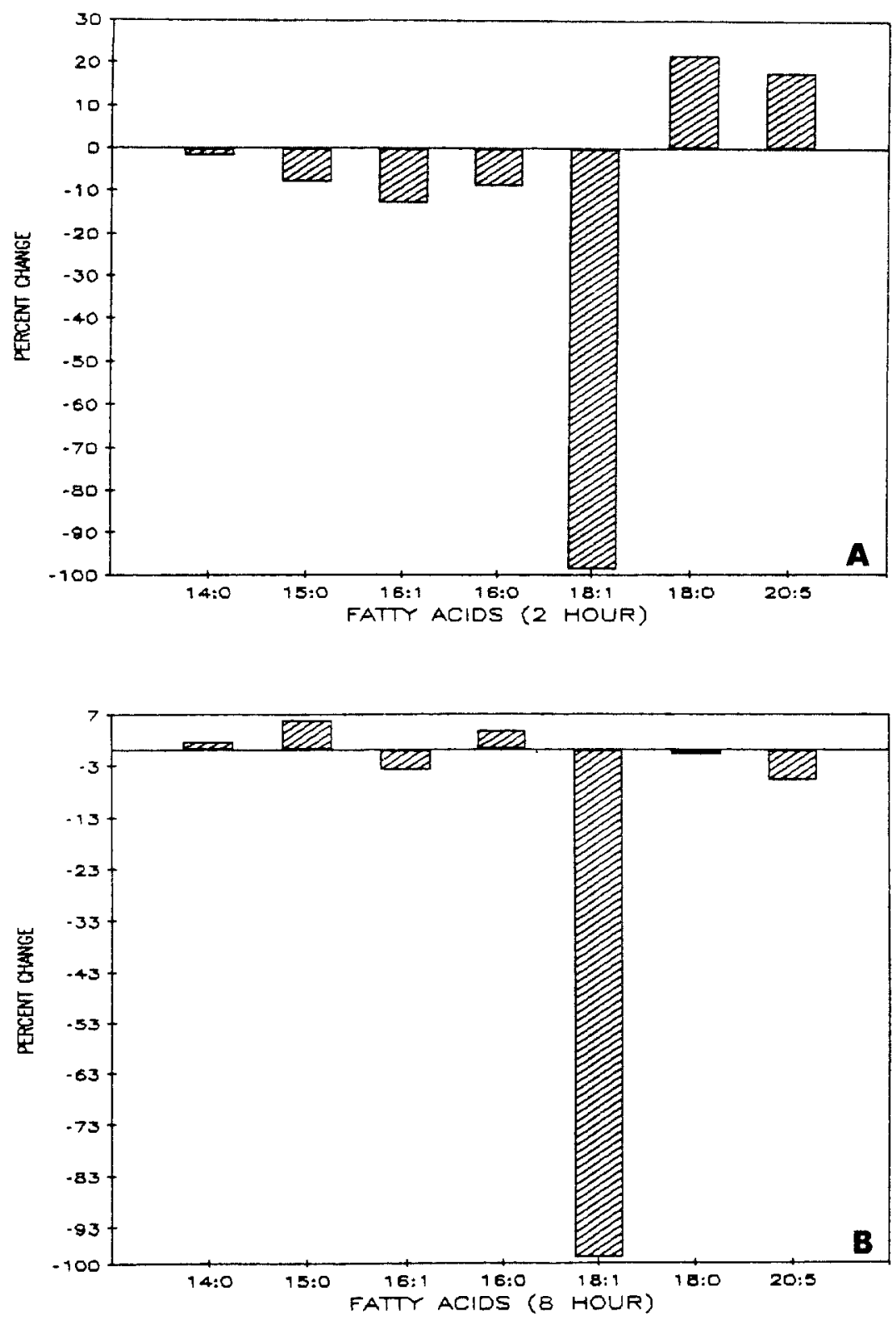

Fig. 7. Changes in fatty acid percent composition with exposure. A $2 \mathrm{hr}$ exposure. B $8 \mathrm{hr}$ exposure
Our data suggest that, at concentrations well below maximum water solubility, partition coefficients cannot be used reliably to predict toxicity. We have suggested (Sicko-Goad et al. 1989a, $1989 \mathrm{~b}, 1989 \mathrm{c})$ that for trichlorobenzene isomers, toxicity was related to a combination of factors including chemical reactivity and physiological state of the cell, particularly lipid content. The data presented in this paper support this hypothesis.

For example, numbers of significant deviations from control cells were plotted for changes greater than $20 \%$ (Figure 9a) and greater than $50 \%$ (Figure $9 b)$. Both figures demonstrate that the numbers of significant changes for the three time periods sampled that were common to all experiments follow a distinct pattern: the results of exposure to $1,2,3-$ and 1,3,5-trichlorobenzene are similar while pentachlorobenzene and 1,2,4-trichlorobenzene are similar. Using a criterion of $50 \%$ change in any category as being significant (Figure 9b), it appears that pentachlorobenzene exposure results in more changes in the first hr and at 5 days of exposure and this in fact may be related to the greater lipophilicity of the compound. However, pentachlorobenzene, which would not be expected to form epoxides or diols, produces similar numbers of effects at 5 days in comparison with 1,2,4-trichlorobenzene, a less lipophilic but potentially more reactive compound. The only explanation that we can offer is that the cells of Cyclotella meneghiniana that were exposed to pentachlorobenzene had a greater lipid content, since these cells were taken 

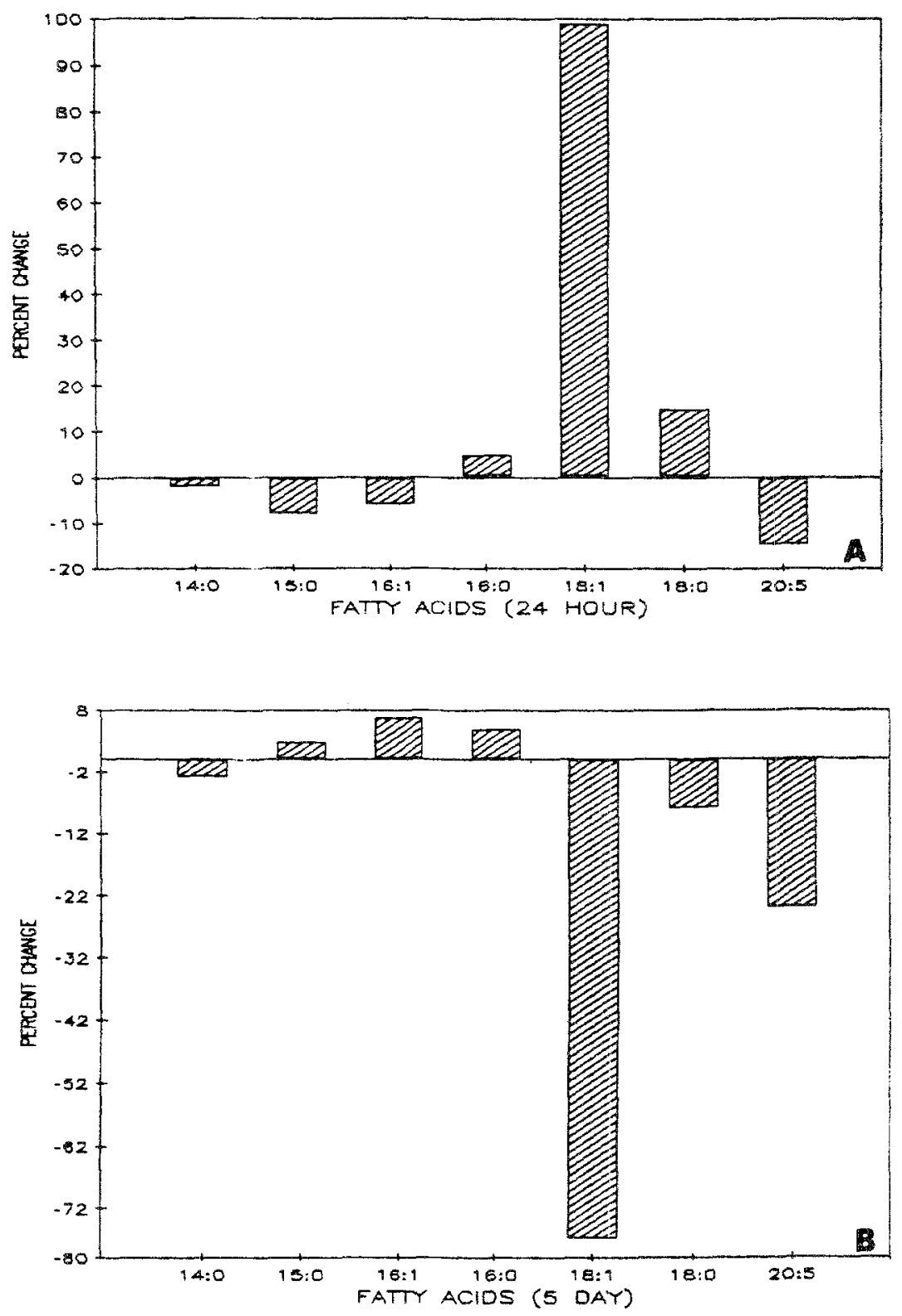

Fig. 8. Changes in fatty acid percent composition with exposure. A 24 br exposure. B 5 day exposure relatively late in the light period, and in fact the 8-hr sample was withdrawn in the first hr and a half of the dark period when lipid volume is at its maximum (Sicko-Goad et al. 1988). So while octanolwater partition coefficients may be useful predictors of acute toxicity and bioaccumulation at high doses (i.e., greater than maximum solubility), they are not as useful in predicting effects at sublethal doses on primary producers.

A comparison of changes in morphological components within common sampling periods for all chlorinated benzene exposure experiments suggests that, in terms of relative volume, some organelles respond more quickly and with greater magnitude than others to chlorinated benzenes. For ex- ample, Figure $10 \mathrm{a}$ demonstrates that chloroplast relative volume appears to be most sensitive to exposure to 1,3,5-trichlorobenzene, but on the whole, is rather insensitive to sub-lethal chlorinated benzene exposure. However, when chloroplast number per volume is plotted (Figure 10b), it is apparent that at eight $\mathrm{hr}$ of exposure there is a reduction in numbers per volume, coupled with an increase in relative volume. Since cell volumes from all treatments were not significantly different, it is apparent that the remaining chloroplasts increased in size to compensate for the reduction in numbers.

Plastoglobuli numbers per volume and relative volume follow the same general pattern for all experiments (Figures 11a, b) and increases and/or de- 

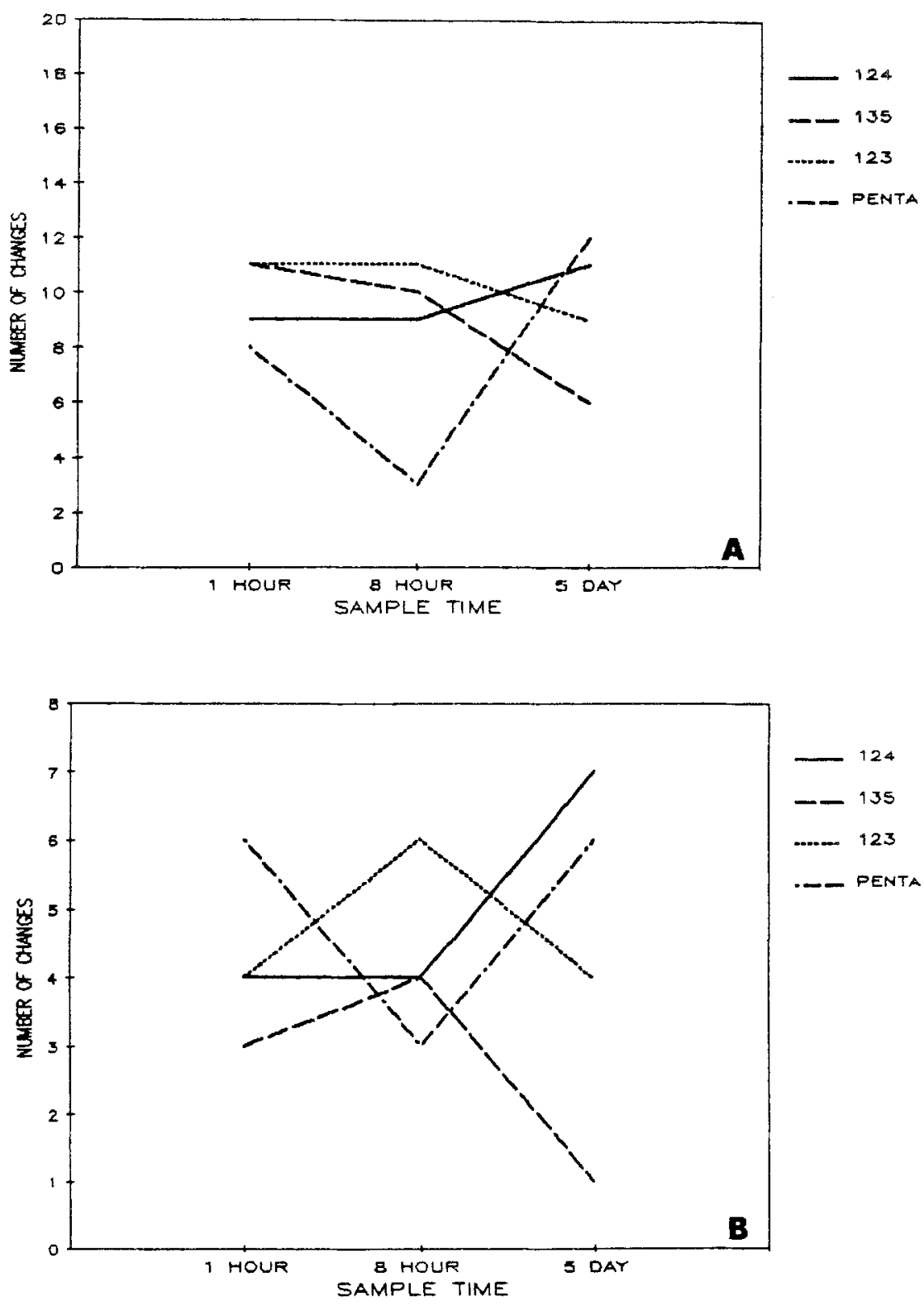

Fig. 9. Significant changes in morphological or fatty acid percent composition with exposure to chlorinated benzenes. A Changes greater than $20 \%$ of the control values. B Changes greater than $50 \%$ of the control values

creases in volume appear to be directly related to numbers. Autophagic-like vacuoles, which are indicative of lytic activity, increase uniformly for all chlorinated benzenes tested (Figure 12) and are still present at 5 days, suggesting continued response to the toxicant.

Based on our results, the toxicity of the chlorinated benzenes that we tested can be rated as follows: $1,2,4-\mathrm{TCB}>1,2,3-\mathrm{TCB}>1,3,5-\mathrm{TCB}>$ Pentachlorobenzene. It is suggested that the physiological state of the cell, particularly lipid content as it relates to light cycle, is responsible for the increased toxicity of 1,2,4-trichlorobenzene. The data suggest that both cell cycle events and environmental parameters that favor lipid production in phytoplankton (e.g., dark, exposure to other toxicants, nitrate starvation) may alter both the timing and magnitude of response to exposure to lipophilic toxicants and may also alter bioaccumulation patterns in aquatic foodwebs.

The sensitivity of algae to toxicants during different seasons of the year and under nutrient deprivation conditions has been suggested by other authors. For example, Hannan and Patouillet (1972) found that mercury toxicity to three algal species increased with decreasing nutrient concentrations. Similarly, Fisher et al. (1976) found that at reduced nitrate levels, the growth of a marine diatom was substantially reduced in the presence of pentachlorobenzene. 

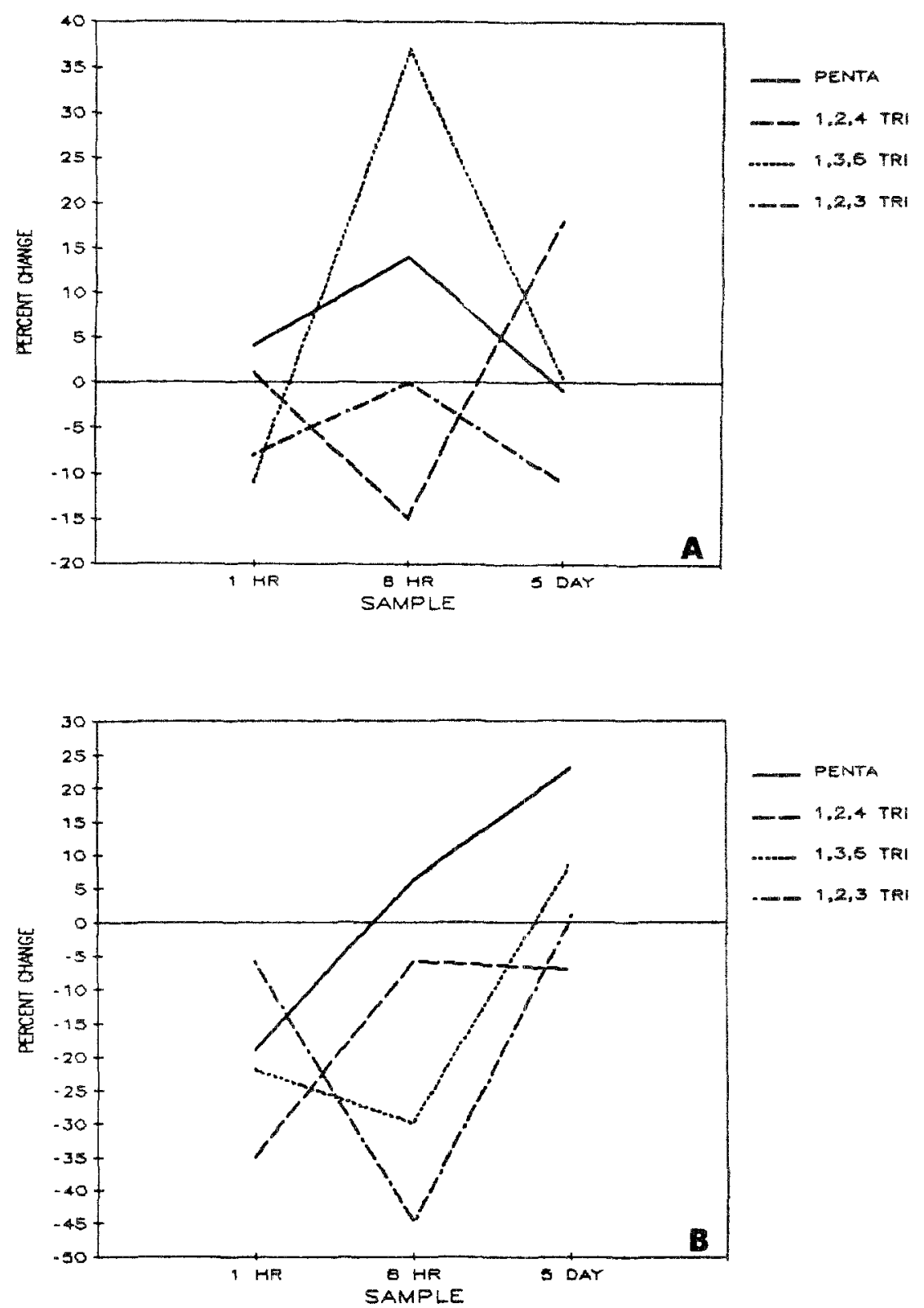

Fig. 10. Percent change in chloroplast relative volume and numbers per volume in sampling times common to all chlorinated benzene exposure experiments. A Chloroplast relative volume $\left(V_{v}\right)$. B Chloroplast $\left(\mathrm{N}_{\mathrm{v}}\right)$

The partitioning of lipophilic toxicants into phytoplankton may result in four equally important ecological perturbations.

1. Lipid-rich metabolically inactive cells may accumulate lipophilic compounds and sink to the sediments resulting in increased sediment burdens of toxicants.

2. The lipid-rich cells may be entrained into the water column to more favorable growth conditions, resulting in the mobilization of lipid for metabolic purposes and subsequent release of the lipophilic toxicant into the cell.

3. The lipid-rich cells may be ingested by either planktonic or benthic herbivores, resulting in biomagnification of toxicants in the foodweb.

4. Planktonic and benthic herbivores may avoid ingesting lipid-rich cells containing lipophilic toxicants. This may result in reduced grazing on the phytoplankton community, resulting in higher standing stocks of phytoplankton and a reduction in herbivore standing stocks.

Such effects are likely to have a major role in the ecotoxicology of lipophilic contaminants in the Great Lakes ecosystem. For example, depositional areas in the offshore regions of the Great Lakes tend to be regions of relatively high concentrations of toxic contaminants (Frank et al. 1979, 1980, 1981). Sediments in such systems are fine-grained and relatively rich in living and dead diatoms (Stoermer et al. 1985). Thus, toxic substances in- 

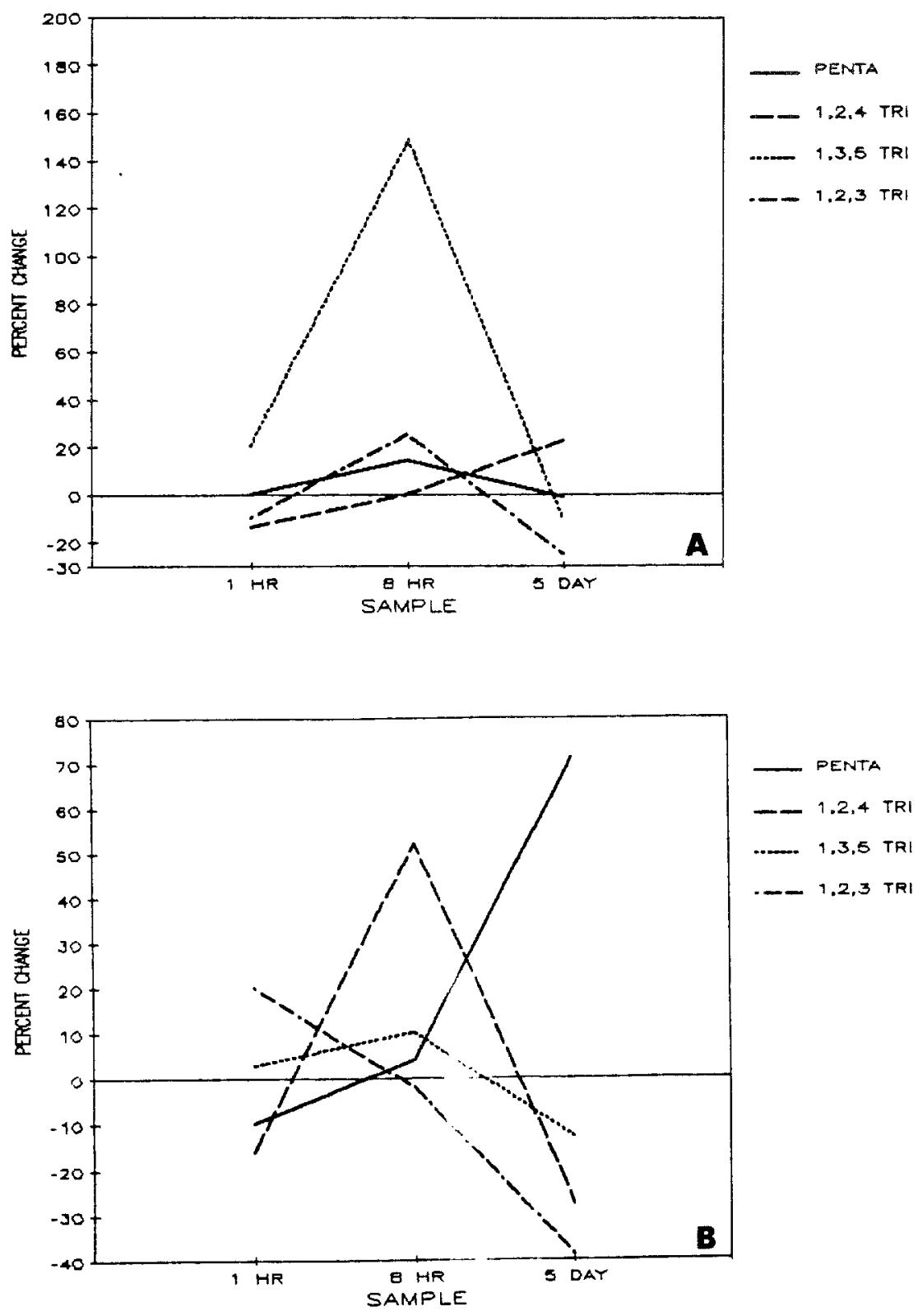

Fig. 11. Percent change in chloroplast lipid relative volume and numbers per volume in sampling times common to all chlorinated benzene exposure experiments. $\mathbf{A}$ Chloroplast relative volume $\left(\mathrm{V}_{\mathrm{v}}\right)$. B Chloroplast $\left(\mathrm{N}_{\mathrm{v}}\right)$

corporated into sedimenting phytoplankton may represent a major depositional pathway from the nearshore to the offshore and from the lake surface to the lake floor.

Sedimenting algae may be entrained into more shallow depths under a variety of physical conditions. The thermocline is eroded during spring and autumn, transporting nutrients and sedimented algae to shallower and more favorable depths (Brooks and Torke 1977).Vertical mixing is especially intense in winter and may reach the lake floor where minerals and sedimented organic matter (including phytoplankton) are resuspended (Eadie et al. 1984). Finally, summer upwelling events transport nutrients and sedimented algae to shallower depths (Schelske et al. 1971), resulting in an increase in phytoplankton productivity.

Toxic substances may be biomagnified when planktonic and benthic herbivores consume contaminant-containing phytoplankton (Reinert 1972; Borgmann and Whittle 1983).This biomagnification appears to be especially significant for offshore populations of benthic invertebrates (Evans et al. 1982; Borgmann and Whittle 1983), possibly because of the interactive effects of relatively high concentrations of contaminants in the planktonic diet and in surficial sediments.

Several studies have shown that zooplankton grazing varies as a function of phytoplankton species composition. Certain species such as blue- 


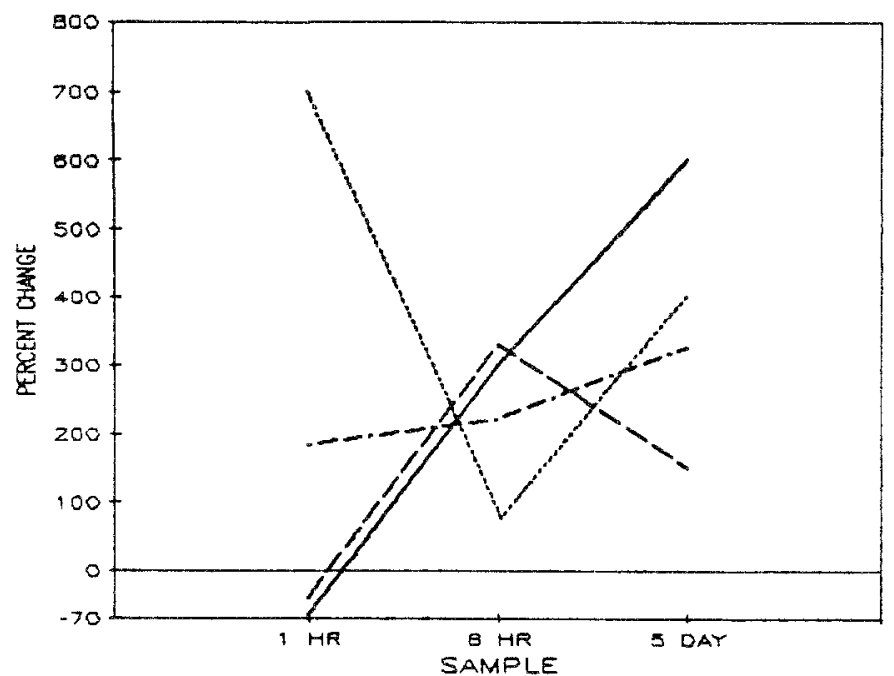

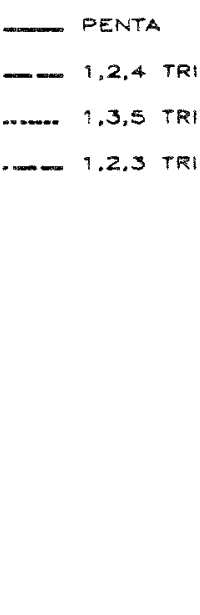

Fig. 12. Percent change in autophagic-like vacuole in sampling time common to all chlorinated benzene exposure experiments green algae and greens are low in food quality and thus inhibit zooplankton grazing (Arnold 1971; Richman and Dodson 1983). More recent investigations have shown that zooplankton can discriminate between nutritionally-poor and nutritionallyrich phytoplankton of the same species (Butler et al. 1987), possibly suggesting that zooplankton may also be able to distinguish between contaminantrich and contaminant-poor cells. Other studies have shown that zooplankton grazing may be inhibited by the presence of toxic substances (McNaught 1982; Gliwicz and Sieniawska 1986). Many of the areas of the Laurentian Great Lakes in which toxic substances are of concern also are areas in which phytoplankton standing stocks are high. Although such large phytoplankton standing stocks have been related to excessive nutrient loadings, reduced zooplankton grazing as a consequence of the presence of toxic substances cannot be discounted as a modifying factor (Evans and McNaught 1988).

Benthic organisms such as amphipods also have been shown to be capable of discriminating against sediments which contain toxic contaminants (Gannon and Beeton 1969). Thus, if sedimented phytoplankton contain high concentrations of toxic substances, this rich source of organic matter may not be consumed by the benthic community. This would result in a reduction in benthic productivity. Alternately, such contaminant-containing cells may be consumed but may adversely affect the benthos, e.g., resulting in deformities in chironomid head capsules (Warwick 1988).

In summary, since numerous pathways for foodweb biomagnification exist, a basic understanding of the mechanisms by which toxicants can alter normal metabolic pathways and by which environmental and physiological parameters can ame- liorate or amplify toxicant effects in phytoplankton is essential for predicting effects in the aquatic ecosystem.

Acknowledgments. We are grateful to Dr. S. S. Kilham for kindly providing the culture of Cyclotella. Supported by grants R-810684 and R-812311 from the Office of Exploratory Research, the United States Environmental Protection Agency. Contribution No. 501 of the Great Lakes Research Division.

\section{References}

Arnold DE (1971) Ingestion, assimilation, survival, and reproduction by Daphnia pulex fed seven species of bluegreen algae. Limnol Oceanogr 16:906-919

Borgmann U, Whittle DM (1983) Particle-size-conversion efficiency and contaminant concentration in Lake Ontario biota. Can J Fish Aquat Sci 40:328-336

Brooks AS, Torke BG (1977) Vertical and seasonal distribution of chlorophyll a in Lake Michigan. J Fish Res Board Can 34:2280-2287

Butler NM, Suttle CA, Neil WE (1987) Discrimination by zooplankton between phytoplankton cells of different nutritional status. Abstract, 50th Amer Soc Limnol Oceanogr Meeting

Eadie BJ, Chambers RL, Gardner WS, Bell GL (1984) Sediment trap studies in Lake Michigan: Resuspension and chemical fluxes in the southern basin. J Great Lakes Res 10:307-321

Evans MS, McNaught DC (1988) The effects of toxic substances on zooplankton populations: a Great Lakes perspective. In: Evans MS (ed) Toxic Contaminants and Ecosystem Health: A Great Lakes Focus. Wiley Interscience. pp 53-76

Evans MS, Bathelt RW, Rice CP (1982) PCBs and other toxicants in Mysis relicta. Hydrobiologia 95:205-215

Fisher NS, Guillard RRL, Wurster CF (1976) Effects of a chlorinated hydrocarbon pollutant on the growth kinetics of a marine diatom. In: Canale RP (ed) Modeling Biochemical Processes in Aquatic Ecosystems. Ann Arbor Science, Ann Arbor, MI, pp 305-317 
Frank R, Thomas RL, Holdrinet M, Kemp ALW, Brown HE (1979) Organochlorine insecticides and PCB in surficial sediments (1968) and sediment cores (1976) from Lake Ontario. J Great Lakes Res 5:18-27

Frank R, Thomas RL, Braun, HE, Rasper J, Dawson R. (1980) Organochlorine insecticides and PCB in the surficial sediments of Lake Superior (1973). J Great Lakes Res 6:113120

Frank R, Thomas RL, Braun, Gross DL, Davies TT (1981) Organochlorine insecticides and PCB in surficial sediments of Lake Michigan. J Great Lakes Res 7:42-50

Gannon JE, Beeton AM (1969) Studies of the effects of dredged materials from selected Great Lakes harbors on plankton and benthos. Univ Wisc-Milwaukee, Center for Great Lakes Studies Special Report No. 8

Geyer H, Politzki G, Freitag D (1984) Prediction of ecotoxicological behaviour of chemicals; Relationship between $n$-octanol/water partition coefficient and bioaccumulation of organic chemical by algae Chlorella. Chemosphere 13:269284

Gliwicz MZ, Sieniawska A (1986) Filtering activity of Daphnia in low concentrations of a pesticide. Limnol Oceanogr 31:1132-1138

Halfon E, Reggiani MG (1986) On ranking chemicals for environmental hazard. Environ Sci Technol 20:1173-1179

Hannan PJ, Patouillet C (1972) Effect of mercury on algal growth rates. Biotech Bioengn 14:93-97

Hutchinson TC, Hellebust J, Tam D, Mackay D, Mascarenhas RA, Shiu WY (1980) The correlation of the toxicity to algae of hydrocarbons and halogenated hydrocarbons with their physical-chemical properties. In: Afghan BK, Mackay D (eds) Hydrocarbons and Halogenated Hydrocarbons in the Aquatic Environment. Plenum, New York. pp 577-586

McNaught DC (1982) Short cycling of contaminants by zooplankton and their impact on Great Lakes ecosystems. J Great Lakes Res 8:360-366

Reinhert RE (1972) Accumulation of dieldrin in an alga (Scendesmus obliquus) Daphnia magna, and the guppy (Poecilia reticulata). J Fish Res Board Can 29:1413-1418
Richman S, Dodson SI (1983) The effect of food quality on feeding and respiration by Daphnia and Diaptomus. Limnol Oceanogr 28:948-956

Schelske CL, Stoermer EF, Feldt LE (1971) Nutrients, phytoplankton productivity and species composition as influenced by upwelling in Lake Michigan. Proc 14th Conf Great Lakes Res, pp 102-113

Sicko-Goad L, Hall J, Lazinsky D, Simmons MS (1989a) Effects of chlorinated benzenes on diatom fatty acid composition and quantitative morphology. II. 1,3,5-trichlorobenzene. Archiv Environ Contam Toxicol 18:638-646

(1989b) Effects of chlorinated benzenes on diatom fatty acid composition and quantitative morphology. III. 1,2,3trichlorobenzene. Archiv Environ Contam Toxicol 18:647655

Sicko-Goad L, Lazinsky D, Hall J, Simmons MS (1989c) Effects of chlorinated benzenes on diatom fatty acid composition and quantitative morphology. I. 1,2,4-trichlorobenzene. Archiv Environ Contam Toxicol 18:629-637

Sicko-Goad L, Simmons MS, Lazinsky D, Hall J (1988) Effect of light cycle on diatom fatty acid composition and quantitative morphology. J Phycol 24:1-7

Stoermer EF, Wolin JA, Schelske CL, Conley DJ (1985) An assessment of ecological changes during the recent history of Lake Ontario based on siliceous algal microfossils preserved in the sediments. J Phycol 21:257-276

Warwick WF (1988) Morphological deformities in Chironomidae (Diptera) larvae as biological indicators of toxic stress. In: MS Evans (ed.). Toxic contaminants and ecosystem health: A Great Lakes focus. John Wiley \& Sons, New York. pp 281-320

Wong, PTS, Chau YK, Rhamey JS, Docker M (1984) Relationship between water solubility of chlorobenzenes and their effects on a freshwater green alga. Chemosphere 13:990996

Manuscript received February 2, 1988. 